\title{
IDEAS FOR AN IMPROVED FORESTRY EDUCATION
}

\author{
N. LUST \\ Laboratory of Forestry, University of Ghent
}

\section{INTRODUCTION}

Education is a subject that always will be discussed. This is a consequence of the differences in insight into the general and specific objectives and into the strategy that should be followed in order to achieve the target. The nature of education is depending on the subject and its actual situation, the acquired knowledge and the overall social characteristics.

Forestry is a specific subject. Its importance differs from region to region. It has multiple functions, so that the various interest groups strive for different objectives. It is therefore not surprizing that forestry education is organized in very different ways. Each type of education should be adjusted continuously to the ever changing specific aims and possibilities. It should be partially adapted to local circumstances, so that a general uniform training system should not be aimed at.

\section{CHARACTERISTICS OF FORESTRY EDUCATION}

Due to the large general interest of the forest, forestry education on an academic level is an absolute necessity. The unfavorable situation of the forest on world scale stresses the need for a scientifically justified forest management. The forest destruction in the tropics, together with the forest decline in the temperate zone, require in the first place a thorough knowledge of the forest ecosystem,in order to preserve these forests or to bring them back in a favorable condition (Hager, 1991). Generally speaking it can be stated, that forestry education aims at the acquiring of the necessary knowledge to achieve the forestry objectives. A university education, however, should not be restricted to a pure vocational training. It should learn the students to understand, examine and solve problems in an independent way. To acquire an integrated insight education should provide a wide basic knowledge, and also take into account the quickly changing social needs. Nevertheless, it cannot be the objective to examine thoroughly all aspects of the subject. There are during the study time, enough possibilities to specialize to some extent in separate areas. It is also important that, next to the theory, the practical approach is enough emphasized (Ottisch, 1989). It is obvious that the objectives can only be achieved, when the necessary means, i.e. personnel and infrastructure, are available (Kucera, 1989). 
Forestry education is very varied in the different countries. For the major part, however,it is based upon the same standards. Next to the basic training, which is mainly mathematically and natural scientifically orientated, Hager (1991) mentions three standards: forestry techniques, forest production and forest economics. A harmonic equilibrium between these groups should exist. At present the relationship in Austria is $1: 1.2: 1.3: 1$. In earlier times, however, mainly the importance of basic training and technique was stressed either more or less. It is obvious that a similar approach of university training has its consequences on forestry practice. The criticism on today's forestry, viz, that it is too one sided technically, productively and economically orientated, is among others the logical consequence of the traditional standards of the forestry education. Therefore forestry has to change its standards. It should, next to necessary technical and economical aspects,emphasize more the biological and social processes.

A certain number of issues are always discussed :

1. A general point of discussion is the duration of the forestry studies. Several authors state that it becomes always longer,eveN too long (Sagh et al., 1986; Findeis et al., 1989: Ottisch, 1989; Schlör et al., 1989; Hager, 1991). Sagl et al. (1986) and also Findeis et al. (1989) indicate that in Austria only $1 \%$ of the students graduate after the legally foreseen study duration of 9 semesters. Average training duration amounts to 14 semesters. Schlör et al. (1989) found in the Federal Republic of Germany, that the duration of the university forestry training lasts 10.1 semesters, but attains at least 7 years of the "Referendar-time" is also taken into account. In order to limit the training period, Sagl and Mauser (1986) propose a.o. the following :

- $\quad$ reduction of the number of teaching hours, coupled with appropriate didactic improvements;

- $\quad$ reduction of the material to the basic questions;

- grouping of courses and reduction of the number of exams (the number of exams has been recently fixed in Ghent on 12 per year).

The authors also plead for more leisure time for the students and for a valuable use of it, in relation with their education. They fear, however, that the situation will lead to a legal extension of the training duration.

2. There is discussion in the importance and the nature of the basic training. Special attention is generally paid to a thorough natural scientific basis (Heinze 1991; Hager, 1991), and an appropriate mathematical knowledge. Besides this, the question always arises : should there be more specialization or more generalization ? Concerning this question, very great differences 
exist between the forestry schools. In some of them no specialization at all is possible, while in others up to $60 \%$ of the subject matter can be chosen freely. However specialization should be mainly aimed at by a thoroughly scientific approach of the common training. Indeed, there is a risk that, due to the great study pressure, even the basics are studied superficially. This way a proper scientific attitude and mind is lost (Sagl and Mauser, 1986). Taking into account the average professional image of graduates, Böhmcker (1991) states that the university training should keep its full width, but that it should make possible at the same time a certain degree of specialization. The real specialization should occur later, by means of permanent training. Heinze (1991) on the contrary, states it somewhat different. He considers that several study directions are advantageous, but that nevertheless graduates should be able to be employed in all fields of forestry.

It is also experienced as a specific problem that an overall vision on the problems does not exists. The connection between the material is not enough stressed. Therefore Hager (1991) pleads for training in integrated courses.

3. Concerning the allocation between theory and practice, great differences also exist between the schools. On one hand a training with $75 \%$ theory and 25 $\%$ practice is possible, while on the other hand also the gaining of practical experience can be stressed (63\%).

It is a fact, that many graduates feel they are insufficiently prepared for their vocation, especially when they still have to acquire, on their own, a specific knowledge. And on the contrary, many have the feeling, they cannot use at all many of the subjects they have learnt at the university. Here the question arises : how large may the gap be between theory and practice. But also an other question can be put : what kind of practice is meant ? Indeed, the professional practice is very different. That explains the very various recommendations, so that it is quite impossible to satisfy all these wishes (Ottisch, 1989).

Moreover it should be taken into consideration that, generally speaking, there is only little certainty of the future vocation and of the prospects.

It is obvious that a practical training is very valuable for each type of forester. Böhmcker (1991) even proposes to lengthen this period from six months to one year.

An other option, however, is to organize a substantial practical training for foresters just entering in service.

4. It is disputable, what kind of entrance conditions there should be. Especially the question of "numerus clausus" is raising. This measure, mainly taken to prevent an overproduction of graduates and to a lesser degree to maintain a high quality training, is really undemocratic, often asocial and against the principles of free choice. Moreover it does not achieve its goal. If this principle should be applied on each level, it would lead to serious social problems. In countries without a "numerus clausus", the employment of 
foresters in other areas than their direct training field, shows that this protectionist measure is actually needless. If necessary it could be replaced by an adequate organization of the training system, whereby a scientific test after one year study could provide the wanted selection.

\section{PROFESSIONAL PROFILE OF THE FORESTER}

In a first approach a number of rather negative features can be observed :

1. The professional prospects for foresters are not so big.

2. The professional field of foresters is rather heterogeneous.

3. The employment situation does not improve very much, although a slight increase is appearing.

4. A great part of the job is administrative.

5. The professional image is not very clear for the students.

Bosch (1981) found that in the former Republic of Germany, at the beginning of the eighties, the need for foresters of all kind of the public services amounted up to 6070 per year. Besides this, Bauer (1979) also calculated an additional need of 10 forestry graduates per year. The small need of foresters also limits considerably the development of the forestry training and research. Society does not consider it useful to build up strongly developed forestry schools and research institutes. In some cases it even considers to stop organizing specific forestry training.

A varied number of forestry graduates is employed in the own field. Others find a job in different fields, often with great success and/or with higher financial wages than the pure foresters.

According to Weiss (1991), 1943 forestry graduates are employed in Austria. About $1 / 3$ is working with public authorities, another third in the forestry service, while the last third is found in training, research, avalanche infrastructure, and other fields. The author states that the traditional professional training is experienced as good and that didactic abilities, knowledge of contact with people and of management can only be achieved outside the university.

Hager (1991) thinks, that the professional situation in forestry will not change very much in the future. A slight increase is expected in the fields of training and research, also due to problems such as forest decline and protection forests. 
A real increase of jobs, however, is expected in the peripheral areas of forestry, but of course the forester has here to take into account the competition of other training fields, such as landscape-planning and -care and nature conservation.

The forester should be in the first place a field manager. But Weiss (1991) finds that, even in private forests, $70 \%$ of the labour is administration, what is to be considered as very inefficient. Moreover, the forester is insufficiently prepared for this tasks. Therefore the author pleads for a course like "forestry administration". From an analysis in Flanders, it appears that the foresters of the external forestry service have the following time schedule :

\begin{tabular}{lccc} 
& average time $(\%)$ & minimum & maximum \\
\hline administration & 40 & 20 & 55 \\
field control & 12 & 5 & 25 \\
meetings & 12 & 5 & 25 \\
thinnings & 10 & 3 & 20 \\
sidelines & 9 & 3 & 20 \\
timber sale & 6 & 1 & 18 \\
others & 6 & 2 & 10 \\
management plans & 6 & 0 & 20 \\
literature & 2 & 0 & 5
\end{tabular}

Administration requires in average $40 \%$, and maximal $55 \%$ of the time. Especially striking is the very little time spent to vocational literature, i.e.to permanent training. All foresters complain that they have insufficient time to work out management plans. Some $60 \%$ of them state they have not enough time for forest controls and thinning exercises.

It appears that forestry students have a bad picture of their prospects. A lot of them start forestry training with the aim to become a forest manager. But after some time it becomes clear to them that their chances are limited. The logical consequence of this is a certain degree of disillusionment and demotivation. The university should give to the applicants a right picture of the professional prospects, whereby the various chances and prospects and also the difficulty of predictions should be pointed out.

Starting from the limiting prospects for foresters in the former Federal Republic of Germany, Schlör et al (1989) made an analysis of vacancies in forestry and peripheral areas. The analysis was especially focused on 476 vacancies, divided as follows: 120 nature conservation, 106 wood industry, 80 landscape-care, 70 forestry, 52 management, 48 foreign aid. Remarkable to this is :

- The field of wood industry is more important than forestry. Yet, the field of foreign aid contains also a lot of foresters.

- $\quad$ The number of jobs in the peripheral areas mainly relates to "the environ- 
ment" sensu lato.

From the analysis, it appears also :

- When recruiting in the forestry field, mostly only the diploma of forestry graduate is required. Age and sex are of little importance. The possession of an additional state exam is favorable.

- In wood industry, the degree of training has less importance. Especially the practical abilities and a commercial attitude with interest for sale and purchase are appreciated.

- $\quad$ A doctoral degree $(\mathrm{PhD})$ is often required in foreign aid. Knowledge of languages, insight into the world forestry and a general economic knowledge are also often required in this field.

- $\quad$ On an average, knowledge of foreign languages is required in 10 to $15 \%$ of the vacancies.

- A good knowledge of data processing is especially wanted in the field of forestry.

- Experience with administration is often wanted, with exception for the field of wood industry.

- Vacancies in the research field are mostly offered in the areas forestry and foreign aid

- As personal characteristics, mainly motivation and organization talent are underlined. Travelling activities are highly appreciated in the field of wood industry, while pedagogic qualities are mainly wanted in the areas of forestry and foreign aid.

- $\quad$ Executive capacities are mainly requested by public or private administrations.

In his evaluation of the forestry training, Böhmeker (1991) mentions a number of strong and weak points. The main strong points are :

1. The central part is taken in by the biological production

2. There is an increasing concern for ecological aspects.

3. The great interest for hunting (?).

4. The personal solidarity of the forester, coupled with a great effort.

Besides these highly appreciated strong points, there is also a large number of weak points :

- The commercial attitude is limited : commercial management, marketing, extension services, knowledge of export

- A limited knowledge of business economics, costs analysis, productivity doctrine

- A shortcoming of technical knowledge, language proficiency and knowledge of business administration. 
- A poor training of personnel matters.

- A lack of flexible organization, of adaptation to changing circumstances.

- Mostly a regional knowledge and thinking, little directed towards international and world situation

- $\quad$ A shortage of knowledge of the development of wood industry.

- Often opposition to extension services.

- $\quad$ Arrears on successful international developments.

- Very slow transfer of research results to practice.

- $\quad$ Often exaggerated attention for game.

This long list of weak points, which is obviously disputable, proves anyway clearly, that the present forestry training can be much improved.

\section{FUTURE NEEDS}

Society, science and forestry are characterized by great dynamics. Therefore it is logical that training should adjust to changing circumstances. Importance and appreciation of the forest will still increase in future. Requirements, put to the forest, will be large and various. Dominant parameters in that integrated system will be : society, ecology and economics (Van Miegroet, 1984; Hofer, 1989; Hager, 1991; Rabl, 1991).

1. The relationship between the forestry sector and the society should be improved. Forestry and forest owner should keep in mind the wishes of the citizens, who want participation in the forest management. Unlike nature conservation, that has won massively the support of the public in a short time, forestry has lost the favor of the public. Forestry should improve to a large extent its public relations. The average citizen will entrust the defense of his interests to the persons and services, who are listening and responding to his complaints. The forester may not be considered as someone who cuts trees and destroys nature. He should act in such a way that he is obviously considered as a conservationist.

2. Forestry should be more concerned with ecological and environmental problems. The forest should be considered and managed as an ecosystem. Handbooks for forest tending, starting from the forest as an ecosystem, should be written. Forestry management should respect the general rules of nature conservation. It should continuously recognize the values of biodiversity, biotope and species protection. The forester should pay more attention to forest preservation, environmental protection, landscape ecology, protection forests and game problems. With that long term aspects should always be borne in mind. 
3. More attention should be paid to the social aspects of forest management. Forestry is considered, more and more, as a public service. For this reason the absence of the study of social and political sciences is considered as a lack in forest education on different levels. Such an acceptance implies the rejection of profit as economic dogma and sole parameter for success.

4. An equilibrium should be found between ecological and social aspects on one hand and economic constraints on the other hand. In comparison with the past, the economical importance of the forest relatively is decreasing. But nevertheless, the direct economical significance of the forest should be continuously stressed by an renewed approach of organization, administration, technique and marketing. This is, of course, mainly important for private forest owners, who, moreover, will be more and more faced with the intervention of public authorities to protect the interests of the population at large.

5. The forester should think more integrated. This follows from two, meanwhile well known, principles : the forest is an ecosystem and it has a multiple function. The future forester should be able to solve problems through an integrated approach of the separate subject fields.

Due to the significance of the forest and thanks to an adequate forestry training, the forester will play in the future not only a role in the forest, but also in related sectors. But on the other hand the forest will not remain the exclusive territory of the forester. The forest will be directed and managed multidisciplinary. If the forester does not adjust effectively the chance will be greater, that in the future the forest service will not be charged anymore with the forest management, but that biologists or ecospecialists will do it.

Böhmcker (1991) tries to derive the central points of the future forestry education from the three major tasks of the forestry, which he formulates as follows :

- The preservation of the forests, of their stability and the assurance of their continuous function fulfillment.

- $\quad$ The assured, continuous production and delivery of wood.

- $\quad$ Forestry should be profitable.

It looks as if an equilibrium exists in this vision between ecology, sociology and economics, but the suspicion is great that in practice priority will be given to profitability. As always, however, the question is : what profitability? How should it be calculated? 
Despite the great differences in vision, the analysis of the present and future forestry permits to formulate some proposals concerning forestry education, which are generally supported.

Reorganization of the study programme should be based upon the needs of the subject.

The curriculum of the forestry training should be renewed partially :

- a thorough knowledge of ecology, of the forest as an ecosystem;

- due attention to social sciences and forest policy;

- development of integrated teaching processes (including self-study, discussions, assignments);

- $\quad$ introduction of new techniques, such as data processing and GIS;

- more emphasis on peripheral subjects, such as nature conservation, environmental protection and landscape-care.

Of course training is not finished after graduation. Permanent training, on all levels, becomes increasingly important. To this, research has a determinant significance. Everyone, as well the field manager, as well as the policy maker and the scientist himself, should obtain the chance to qualify permanently in new insights and techniques.

Optimization of training is very difficult. Differences in opinions and interests lead to disputable objectives. Society is often not able to provide the necessary means. Moreover the final organization holds all kind of problems.

Education is no longer a national matter. With respect to the content as well as to the organization, training will have to be regulated in the future on a more international level. An example of that is the Erasmus programme, which is in full development in the European Union. Although this programme undoubtedly contains very valuable elements, the practice is not always so positive. The differences between the European training systems are, in many respects, still to large. One should strive for a greater uniformity without abandoning the specific, own characters. It looks as if a satisfactory solution will require still much time. 


\section{CONCLUSIONS}

Forestry training must be adjusted continuously to the changing characteristics of forestry, scientific knowledge and social requirements. The relationship between the traditional standards of the forestry training, viz. forestry technique, forest production and forest economics is jointly responsible for the unfavorable images of today's forestry.

Forestry training is negatively affected by the rather bad professional image of a forester. The employment situation is limited, and also the prospects. The professional field of foresters is very heterogeneous. Forestry students are, in the beginning, insufficiently informed of their prospects.

Foresters have a number of strong points, such as their knowledge of biological production, their concern for ecological aspects, their engagement and their feeling for responsibility. But also a number of weak points can be listed : poor commercial mind, shortage of technical knowledge, insufficient social training, etc.

In the future above all the relationship between the forestry sector and the society has to be improved. The forester will have to pay more attention to ecological and environmental problems and also to the social aspects of forest management.

$\mathrm{He}$ will have to look for an equilibrium between the ecological, social and economic functions of the forest. He must be able to solve any problem through an integrated approach.

Concrete proposals for an immediate adjustment of training, at least with respect to the content, are : more emphasis on ecological aspects, social sciences, integrated training, general economics, commercial and administrative principles, recent technologies such as date processing and GIS, and also of several peripheral subjects, such as environmental protection, nature conservation and landscape care. Of course, permanent training is an absolute necessity.

A good forestry training should lead to a thorough insight into the forest ecosystem and to a positive attitude towards the forest.

\section{REFERENCES}

Anonymus, 1990. Forestry research. National research council, National Academy Press, Washington, D.C., 84 p.

Bauer, K., 1979. Die Nachwuchssituation im Forstdienst. Allgemeine Forstzeitschrift 34, 679-702.

Bosch, R., 1981. Berufsaussichten der Assessoren des Forstdienstes. Allgemeine 
Forstzeitschrift 36, 1234-1235.

Findeis, G. and G. Rothleitner, G., 1989. Quo vadis Forststudium ? Österreichische Forstzeitung 100, 61.

Gülen, I., 1989. Die Forstliche Fakultät der Universität Istambul. Forst und Holz 44, 545-547.

Hager, H., 1991. Forstberufliche Zukunft. Ausbildung in Vergangenheit, Gegenwart und Zukunft. Österreichische Forstzeitung 102, 45-47.

Heinze, M., 1991. Die forstliche Lehre an der Hochschule Tharandt. Allgemeine Forstzeitschrift 46, 835-837.

Hofer, P., 1989. Lehre und Forschung für die Holzwirtschaft an der ETH Zürich aus ökonomischer Sicht. Schweizerische Zeitschrift für Forstwesen 140, 885-898

Kucera, J., 1989. 30 Jahre Holzwissenschaft an der ETH Zürich : Rückblick und Ausblick. Schweizerische Zeitschrift für Forstwesen 140, 847-867.

Militon, J., 1988. Forstliche Ausbildung in Frankreich. Holzcentralblatt 114, p. 788.

Ottisch, A., 1989. Berufsvorbereitung auf der Universität- ein Wunschtraum ? Österreichische Forstzeitung 100, 60-61.

Rabl, K., 1991. Waldbau heisst Integration aller Fachgebiete. Österreichische Forstzeitung 102, 30-31.

Sagh, W. and H. Mauser, 1986. Eine Studienablaufanalyse am Beispiel des Studienzweiges "Forstwirtschaft". Allgemeine Forstzeitschrift 41, 371-373.

Salomon, L., 1988. Bringt der neue Lehrplan eine Verbesserung der Försterausbildung ? Österreichische Forstzeitschrift 99, 12-13.

Schlör, P.; S. Schwab; F. Kreutle and U. Finkner, 1989. Berufschancen für Forstakademiker, dargestellt an hand einer Stellenanalyse des AKFB. Forst und Holz 44, 312316.

Van Miegroet, M., 1984. Reflections on the position of the forest and of forestry in Europe. Silva Gandavensis 50, 101-111.

Weiss, K., 1991. Ausbildung nicht nur zur Wirtschafts-führer. Österreichische Forstzeitung 102, p. 47. 
